\title{
Feasibility Study on Vitrification for Rare Earth Wastes of PyroGreen Process
}

\section{파이로그린공정 희토류폐기물 유리화 타당성 연구}

Cheon-Woo Kim* and Byeong Gwan Lee

Central Research Institute of KHNP, 1312-70 Yuseong-Daero, Yuseong-Gu, Daejeon

김천우*, 이병관

한국수력원자력(주) 중앙연구원, 대전광역시 유성구 유성대로 1312 번길 70

(Received October 24, 2012 / Revised December 17, 2012 / Approved January 28, 2013)

The rare earth oxide wastes consisting of major 8 nuclides $\mathrm{Y}, \mathrm{La}, \mathrm{Ce}, \mathrm{Pr}, \mathrm{Nd}, \mathrm{Sm}, \mathrm{Eu}$ and Gd, are generated during the salt waste treatment of PyroGreen process. The final form of the rare earth is generated as the oxide state. In this study, six candidate glasses were developed to evaluate the feasibility for vitrifying the rare earth oxide wastes within the borosilicate glass system.

The solubilities of the mixture of the rare earth oxide waste showed less than $25 \mathrm{wt} \%$ at $1,200^{\circ} \mathrm{C}$, less than $30 \mathrm{wt} \%$ at $1,300^{\circ} \mathrm{C}$, respectively. It means that solubility is increased with the temperature increment. The liquidus temperature of the homogeneous glass with $20 \mathrm{wt} \%$ waste loading was determined as less than $950^{\circ} \mathrm{C}$. In more than solubility of rare earth oxides glass, formation of rare earth-oxide-silicate crystal in glass-ceramic occurred as the secondary phase. As their viscosity at melting temperature $1,200 \sim 1,300^{\circ} \mathrm{C}$ was less than 100 poise, electrical conductivity was higher than 1 S/cm, 20 25wt\% waste loading glasses with good surface homogeneity are judged to have good operability in cold crucible induction melter. Other physicochemical properties of the developed glasses are going to be experimented in the future.

Key words: PyroGreen, Vitrification, Rare earth oxide, Glass formulation, Waste solubility

파이로그린공정의 염폐기물처리과정에서 발생되는 주요 산화물 형태의 폐기물에는 희토류폐기물이 있으며 주요 구성 핵 종은 $\mathrm{Y}, \mathrm{La}, \mathrm{Ce}, \mathrm{Pr}, \mathrm{Nd}, \mathrm{Sm}, \mathrm{Eu}, \mathrm{Gd}$ 등 8종이다. 최종적인 희토류폐기물의 형태는 산화물 형태로 발생된다. 본 연구에서는 붕 규산 유리계 내에서 희토류 산화물의 유리화 타당성을 평가 하기 위하여 6종의 유리조성을 개발하였다.

희토류 8 핵종 혼합에 대한 solubility는 $1,200^{\circ} \mathrm{C}$ 에서 $25 \mathrm{wt} \%$ 미만, $1,300^{\circ} \mathrm{C}$ 에서 $30 \mathrm{wt} \%$ 미만 waste loading으로 온도 상승에 따라 증가하는 것으로 나타났으며 liquidus temperature는 균질한 유리가 형성된 $20 \mathrm{wt} \%$ waste loading 에서 $950^{\circ} \mathrm{C}$ 이하로 평 가되었다. 희토류 산화물의 유리매질 내 solubility 이상에서는 희토류-oxide-silicate 결정이 생성된 유리세라믹을 이차상으로 형성하였으며 20 25wt\% waste loading의 표면균질성이 양호한 유리는 용융온도 $1,200 ~ 1,300^{\circ} \mathrm{C}$ 범위에서 점도 100 poise 이 하, 전기전도도 $1 \mathrm{~S} / \mathrm{cm}$ 이상으로 유도가열식 저온용융로설비에서의 운전 용이성이 매우 양호한 것으로 평가되었다. 개발된 유리조성에 대한 기타 물리·화학적 특성 평가를 위한 실험들이 향후 수행될 예정이다.

중심단어: 파이로그린, 유리화, 유리세라믹화, 희토류, 폐기물

*Corresponding Author . E-mail: cheonkim@khnp.co.kr, Tel: +82.42.870.5460 


\section{1. 서 론}

파이로프로세싱의 종전 제염계수를 20배 이상 증가시켜 사용후핵연료 재활용공정에서 발생하는 모든 고준위폐기 물을 중준위로 변환하는 파이로그린(PyroGreen)공정에 대 한 검증연구가 수행되고 있다. 파이로그린공정의 염폐기물 처리과정에서 희토류 핵종을 포함하는 공융염폐기물이 발 생하는데 여기서 희토류 핵종을 분리하여 적정한 방법으로 고화 처리하여야 한다.

희토류 원소는 주기율표 III족에 속하는 Sc, Y과 란탄족 15 원소(Ce, Pr, Nd, Pm, Sm, Eu, Gd, Tb, Dy, Ho, Er, Tm, Yb, $\mathrm{Lu}$ ) 등 17 원소를 말한다. 경수로 사용후핵연료의 건식처리 과정에서 발생하는 희토류폐기물의 핵종은 $\mathrm{Y}, \mathrm{La}, \mathrm{Ce}, \mathrm{Pr}$, $\mathrm{Nd}, \mathrm{Pm}, \mathrm{Sm}, \mathrm{Eu}, \mathrm{Gd}, \mathrm{Tb}, \mathrm{Dy}, \mathrm{Ho}, \mathrm{Er}, \mathrm{Tm}$ 등인데 이 중에서 $\mathrm{Y}, \mathrm{La}, \mathrm{Ce}, \mathrm{Pr}, \mathrm{Nd}, \mathrm{Sm}, \mathrm{Eu}, \mathrm{Gd}$ 등 8핵종이 $99.7 \%$ 를 차지하 고 있으며 발열량의 $87 \%$ 는 Y에 의해서 발생한다[1].

전해정련 공융염폐기물 내에 존재하는 희토류 염화물 핵 종은 산소와의 반응을 통해 핵종별로 안정된 형태의 옥시 염화물(Oxychloride)이나 산화물(Oxide) 형태로 공융염에 서 $99 \%$ 이상 분리, 제거된다. 옥시염화물 $(\mathrm{REOCl})$ 로 형성되 는 희토류는 $\mathrm{Eu}, \mathrm{Gd}, \mathrm{Sm}, \mathrm{La}, \mathrm{Nd}, \mathrm{Pr}$ 이고 산화물 형태로 침 전되는 희토류는 $\mathrm{Ce}, \operatorname{Pr}\left(\mathrm{REO}_{2}\right), \mathrm{Y}\left(\mathrm{RE}_{2} \mathrm{O}_{3}\right)$ 이다. 이 중 $\mathrm{Pr}$ 은 옥시염화물과 산화물로 모두 형성된다. 침전물들은 구 조적으로 작은 크기를 가지는 cubic형태의 산화물과 큰 크 기를 가지는 tetragonal 형태의 옥시염화물로 혼합되어 있 다[2][3][4].

란탄족 원소들은 유리 내에서 밀도를 증가시키고 점도 및 전기저항을 감소시키는 작용을 하며 화학적 내구성을 저하 시키지는 않는다. 붕규산유리에 시험된 $\mathrm{Nd}_{2} \mathrm{O}_{3}$ 의 최대 조 성비는 $20 \mathrm{wt} \%$ 였는데 산화물이 유리특성에 미치는 영향은 무시할 정도였다. $\mathrm{La}$ 는 $\mathrm{Ba}$ 과 유사한 굴절률을 증가시키는 광학적 특성을 가지며 유리 내에서의 물리적 특성은 $\mathrm{Ce}$ 과 비슷하다. 붕규산유리계에서 소량의 $\mathrm{La}_{2} \mathrm{O}_{3}$ 는 $\mathrm{PbO}$ 와 유사 한 열팽창 및 점도증가를 일으키고 소량의 첨가로도 화학 적 내구성을 개선시킨다. 붕규산유리계에 시험된 $\mathrm{La}_{2} \mathrm{O}_{3}$ 의 최대조성은 $2 \mathrm{wt} \%$ 였는데 산화물의 유리특성에 미치는 영향 이 무시할 정도여서 더 많은 양의 $\mathrm{La}_{2} \mathrm{O}_{3}$ 가 유리에 포함될 수 있다고 여겨진다.

염폐기물처리과정에서 분리되는 희토류 산화물은 안정 한 물질로서 발열량이나 방사능이 크게 높지 않아 유리고화 하거나 세라믹고화하는 연구가 진행되고 있다. 초우란 물 질의 고화체 제조연구에서 대체물로 희토류 원소인 $\mathrm{Nd}, \mathrm{Ce}$
산화물의 붕규산유리계에 대한 용해도가 연구되었다[5]. 희 토류 산화물을 세라믹 물질로 고화하는데 있어서 비교적 저 온조건에서 합성이 가능한 물질은 악티나이드 고정화 광물 로서 많이 연구되고 있는 모나자이트 $\left(\mathrm{REPO}_{4}\right)$, 아파타이트 $\left[\mathrm{Ca}_{4}-\mathrm{xRE}_{6}+\mathrm{x}\left(\mathrm{SiO}_{4}\right)_{6}-\mathrm{y}\left(\mathrm{PO}_{4}\right) \mathrm{y}(\mathrm{O}, \mathrm{F})_{2}\right]$ 등이 있다[6][7].

염폐기물처리과정에서 분리되는 분말상의 희토류 산화 물로만 구성된 방사성폐기물의 고화체 제조에 대한 연구 는 국내 한국원자력연구원(KAERI)에서 수행하고 있는 것 으로 파악되고 있다. KAERI는 프랑스에서 고준위폐기물의 유리고화체 제조에 사용되는 붕규산유리계인 R7T7 유리매 질에 의한 희토류 산화물 고화체, 희토류 산화물을 희토류 모나자이트(RE-monazite)로 합성 후 붕규산유리계에 의한 고화체 및 모나자이트계 세라믹고화매질인 $\mathrm{CaHPO}_{4}-\mathrm{ZnO}$ - $\mathrm{TiO}_{2}-\mathrm{SiO}_{2}-\mathrm{B}_{2} \mathrm{O}_{3}$ 로 구성된 $\mathrm{ZIT}$ (Zinc Titanate) 고화매질 을 이용한 희토류 산화물 고화체 등 3종의 고화체를 제조 하여 침출 및 물리화학적 특성을 비교 평가하였다. 이 연구 결과에서 고상소결에 의해 제조된 ZIT 매질 희토류 고화체 가 내침출성 및 밀도가 높고 열전도도 특성이 우수한 것으 로 나타내었다[8].

본 연구에서는 KAERI 연구와 같이 분말상의 희토류 산 화물만의 유리고화체를 제조 실험하였다. 그러나 고화매질 은 KAERI의 R7T7과 다른 유리를 사용하였고 희토류 산화 물 waste loading도 20wt $\%$ 로 고정하지 않고 20 40wt $\%$ 로 변화를 주었으며 사용 희토류 핵종 수도 4 핵종이 아닌 8핵 종으로 하였다. 처분 안전성을 높이고 부피 최소화를 만족 하는 고화기술 개발을 연구목표로 정하고 희토류폐기물 유 리화의 최적 유리조성을 위한 절차 및 삼상좌표를 수립 활 용하였으며 단계별로 2 개씩의 유리고화체를 제작 평가한 후 분석결과에 따라 베이스유리와 waste loading을 변화 시키면서 총 6 개의 희토류폐기물 유리고화체를 제조하여 균질성, 상안정성, 용해도, 열전도도 등 특성을 측정 분석 하였다.

\section{2. 실험방법}

\section{1 실험절차}

희토류폐기물 유리화의 최적 유리조성 개발을 위해 Fig. 1 과 같은 절차를 수립하여 실험을 수행하였다. 또한 삼상 좌표(Fig. 2)를 이용하여 유리고화체 품질 우수영역, 프 로세스 최적영역 및 최대 감용비 달성영역을 도출하고 자 하였다. 


\section{2 유리고화체 제조}

유리품질, 감용비 및 프로세스 영역을 모두 만족하는 최적 유리조성을 도출하기 위한 희토류폐기물 유리고화체를 제 조하였다. 유리고화체 제조에 사용된 베이스유리 산화물은 $\mathrm{B}_{2} \mathrm{O}_{3}, \mathrm{Li}_{2} \mathrm{O}, \mathrm{Na}_{2} \mathrm{O}, \mathrm{SiO}_{2}$ 등 4종이고 조성은 화학적 내성 및 점도 등을 고려하여 조절하였다.

희토류핵종은 파이로그린공정의 전해정련 공융염폐기 물에 주로 포함되어 있는 8종(Y, La, Ce, $\mathrm{Pr}, \mathrm{Nd}, \mathrm{Sm}, \mathrm{Eu}$, $\mathrm{Gd}$ )이며 $\mathrm{CeO}_{2}, \mathrm{Eu}_{2} \mathrm{O}_{3}, \mathrm{Gd}_{2} \mathrm{O}_{3}, \mathrm{La}_{2} \mathrm{O}_{3}, \mathrm{Nd}_{2} \mathrm{O}_{3}, \mathrm{PrO}_{2}, \mathrm{Sm}_{2} \mathrm{O}_{3}$, $\mathrm{Y}_{2} \mathrm{O}_{3}$ 를 사용하였다. 희토류 산화물 조성은 Table 1에 나 타낸 PWR 사용후핵연료 속에 포함된 희토류폐기물의 핵 종별 비율에 근거하였다[1]. 희토류 산화물을 20 40wt $\%$ waste loading에 따라 총 6개의 희토류폐기물 유리고화체 (PG4 PG9)를 제조하였다. 희토류폐기물 유리고화체에 대 한 조성은 Table 2에 나타내었다.

희토류폐기물 유리고화체의 조성에 맞게 혼합되어진 100 $\mathrm{g}$ 의 유리 배치(glass batch)를 열적 안정성이 높은 점토도 가니(clay crucible)에 담아 $\mathrm{MoSi}_{2}$ 발열체 전기로(고려전기

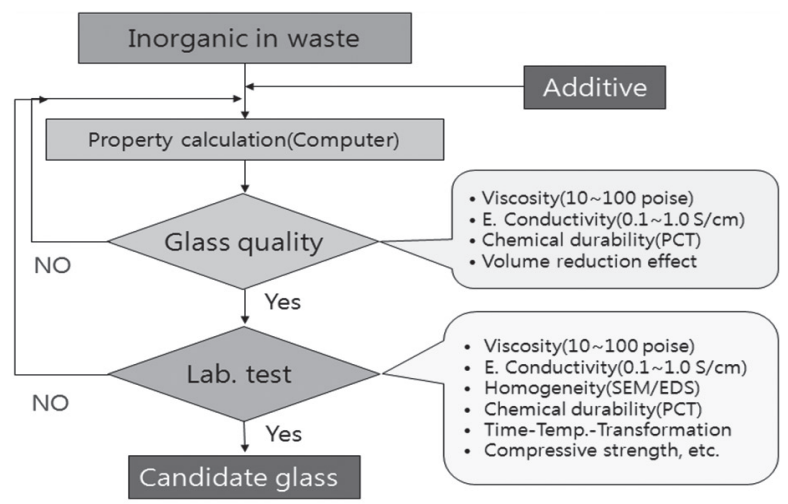

Fig. 1. Glass formulation development flow chart.

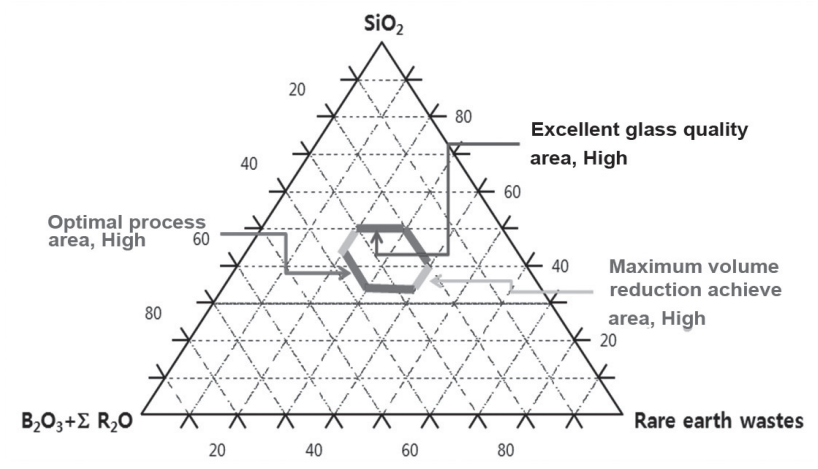

Fig. 2. Ternary diagram for deriving the optimal area of glass composition.
Table 1. Ratio of rare earth nuclides contained in the PWR spent fuel

\begin{tabular}{cc}
\hline Nuclides & Ratio(wt\%) \\
\hline $\mathrm{Y}$ & 4.55 \\
\hline $\mathrm{La}$ & 11.77 \\
\hline $\mathrm{Ce}$ & 22.98 \\
\hline $\mathrm{Pr}$ & 10.78 \\
\hline $\mathrm{Nd}$ & 39.16 \\
\hline $\mathrm{Sm}$ & 7.87 \\
\hline $\mathrm{Eu}$ & 1.50 \\
\hline $\mathrm{Gd}$ & 1.05 \\
\hline $\mathrm{Pm}$ & 0.29 \\
\hline $\mathrm{Tb}$ & 0.02 \\
\hline $\mathrm{Dy}$ & 0.01 \\
\hline $\mathrm{Ho}$ & 0.001 \\
\hline $\mathrm{Er}$ & 0.001 \\
\hline $\mathrm{Tm}$ & 0.0000004 \\
\hline $\mathrm{Total}$ & 100.00
\end{tabular}

Table 2. Compositions \& characteristics of candidate glasses(wt\%)

\begin{tabular}{|c|c|c|c|c|c|c|c|}
\hline composition & $\begin{array}{l}\text { glass } \\
\text { name } \\
\text { oxides }\end{array}$ & PG4 & PG5 & PG6 & PG7 & PG8 & PG9 \\
\hline \multirow{4}{*}{$\begin{array}{c}\text { base } \\
\text { glasses }\end{array}$} & $\mathrm{B}_{2} \mathrm{O}_{3}$ & 7.38 & 8.00 & 8.00 & 10.00 & 10.71 & 11.43 \\
\hline & $\mathrm{Li}_{2} \mathrm{O}$ & 2.77 & 3.00 & 3.00 & 3.00 & 3.21 & 3.43 \\
\hline & $\mathrm{Na}_{2} \mathrm{O}$ & 15.69 & 17.00 & 24.00 & 22.00 & 23.57 & 25.14 \\
\hline & $\mathrm{SiO}_{2}$ & 34.16 & 37.00 & 35.00 & 35.00 & 37.51 & 40.00 \\
\hline \multirow{8}{*}{$\begin{array}{l}\text { rare earth } \\
\text { wastes }\end{array}$} & $\mathrm{CeO}_{2}$ & 9.51 & 8.32 & 7.13 & 7.13 & 5.94 & 4.75 \\
\hline & $\mathrm{Eu}_{2} \mathrm{O}_{3}$ & 0.54 & 0.48 & 0.41 & 0.41 & 0.34 & 0.27 \\
\hline & $\mathrm{Gd}_{2} \mathrm{O}_{3}$ & 0.46 & 0.40 & 0.34 & 0.34 & 0.28 & 0.23 \\
\hline & $\mathrm{La}_{2} \mathrm{O}_{3}$ & 4.67 & 4.08 & 3.50 & 3.50 & 2.92 & 2.33 \\
\hline & $\mathrm{Nd}_{2} \mathrm{O}_{3}$ & 15.42 & 13.50 & 11.57 & 11.57 & 9.65 & 7.71 \\
\hline & $\mathrm{PrO}_{2}$ & 4.47 & 3.91 & 3.35 & 3.35 & 2.79 & 2.23 \\
\hline & $\mathrm{Sm}_{2} \mathrm{O}_{3}$ & 2.98 & 2.61 & 2.24 & 2.24 & 1.86 & 1.49 \\
\hline & $\mathrm{Y}_{2} \mathrm{O}_{3}$ & 1.95 & 1.71 & 1.46 & 1.46 & 1.22 & 0.98 \\
\hline \multicolumn{2}{|c|}{ waste loading } & 40 & 35 & 30 & 30 & 25 & 20 \\
\hline
\end{tabular}

로)를 이용하여 $10^{\circ} \mathrm{C} / \mathrm{min}$ 의 승온속도로 $1,200^{\circ} \mathrm{C}$ 까지 가열 하였다. $1,200^{\circ} \mathrm{C}$ 도달시점에서 점토도가니를 꺼내 용융물 을 석영봉으로 균질하게 재혼합한 후 다시 전기로에 넣어 $1,200^{\circ} \mathrm{C}$ 에서 1 시간 동안 용융한 다음 흑연몰드에 부어 자연 냉각하였다.

\section{3 유리고화체 특성평가}

희토류폐기물 유리고화체의 표면 균질성은 주사전자현미 
경(SEM : Scanning Electron Microscope, JEOL, JSM-5600) 으로 측정하여 표면을 관찰하였으며 에너지 분산형 분광 기(EDS : Energy Dispersive Spectroscopy, Oxford, INCA Energy)를 사용하여 표면을 정성분석하였다. SEM/EDS 측 정에 적합하도록 지름 $1 \mathrm{~cm}$ 이내의 유리고화체 시료를 채 취하여 시편연마기에서 표면을 고르게 연마한 후 카본 코 팅하였다.

액상온도의 평가를 위하여 표면 균질성이 양호한 시료 를 백금도가니에 $10 \mathrm{~g}$ 을 취해 전기로에서 $950^{\circ} \mathrm{C} / 20$ 시간 열 처리 하였다. 열처리 종료 시점에서 백금도가니를 꺼내 상 온의 물에서 급냉각(quenching)하여 유리의 결정 형성 여 부에 따라 액상온도를 평가하였다. 열처리된 유리의 SEM/ EDS 분석을 위한 전처리는 유리고화체 분석 전처리와 동일 한 방법으로 수행하였다.

유리매질 내에서 희토류폐기물의 용융온도에 따른 solubility를 평가하기 위해 $1,200^{\circ} \mathrm{C}$ 로 용융 제조한 시료 (PG4 PG9)에서 알루미나 도가니(alumina crucible)에 각 $50 \mathrm{~g}$ 씩을 취해 $1,300^{\circ} \mathrm{C}$ 에서 용융 제조(PG4-1 PG9-1)하여 $\mathrm{SEM} / \mathrm{EDS}$ 분석을 실시하였다. 유리고화체의 화학적 내구 성 평가를 위하여 PCT (Product Consistency Test) 결과

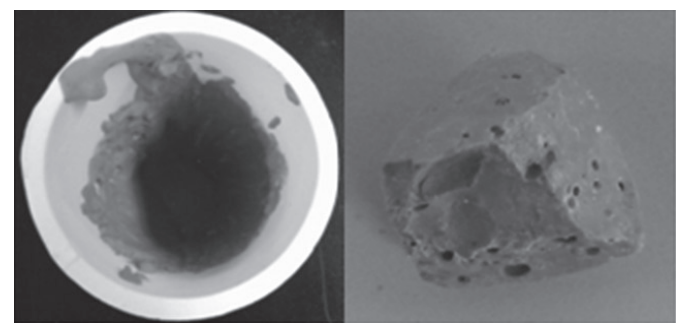

(a) PG4

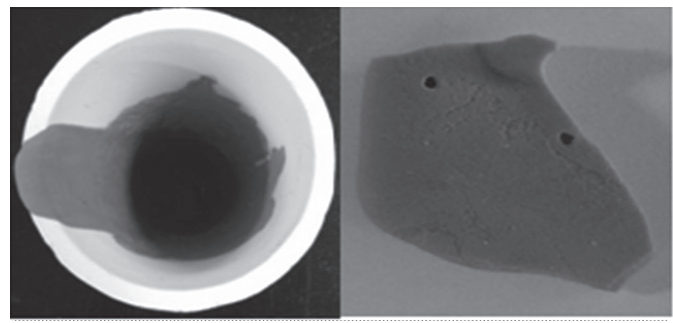

(c) PG6

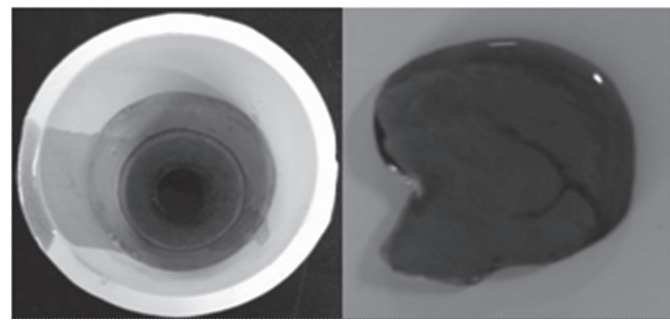

(e) PG8
를 예측할 수 있는 컴퓨터 프로그램(GlassForm 1.1)을 사 용하였다[9].

\section{3. 결과 및 고찰}

\section{1 유리용융상태}

제조유리의 용융상태 모습, 부어지는 정도, 혼합상태 등 을 Fig. 3에 나타내었다. (a) PG4, (b) PG5는 균일하게 혼합 되지 않았고 높은 점도로 인해 용융유리의 부어지는 정도가 매우 불량하여 점토도가니를 파쇄하여 시료를 채취하였다. (c) PG6, (d) PG7의 경우 부어지는 정도는 약간 양호하였으 나 균일하게 혼합되지는 않았다. 반면에 (e) PG8과 (f) PG9 는 부어지는 정도가 매우 양호하였고 균일하게 혼합되었으 며 낮은 점도로 인해 점토도가니 내부 침식이 보였다.

\section{2 균질성(homogeneity) 평가}

유리고화체의 표면 균질성을 평가한 SEM/EDS 분석결과

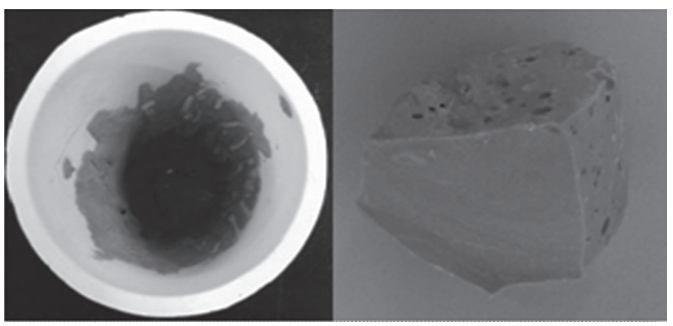

(b) PG5

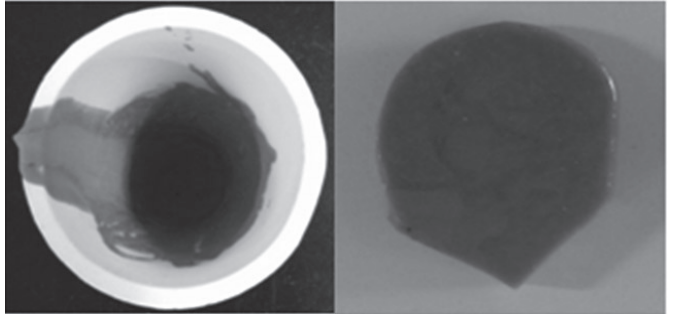

(d) PG7

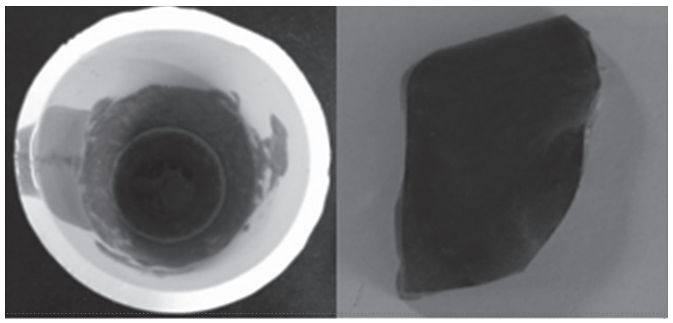

(f) PG9

Fig. 3. Melting status of glasses containing rare earth oxides. 
를 Fig. 4에 나타내었다. A의 SEM image에서 (a) PG4 (e) PG8은 결정이 생성되어 표면이 불균질하였으나, (f) PG9 는 결정상 없이 균질한 것으로 분석되었다. 균질한 유리부 분을 측정한 $\mathrm{EDS}$ spectrum B와 결정 부분을 측정한 $\mathrm{EDS}$ spectrum C의 비교를 통해 희토류 산화물의 결정생성을 확
인할 수 있다. 희토류가 유리상으로 다 용해되지 않고 결정 화되어 남아있는 부분의 $\mathrm{EDS}$ 스펙트럼을 보면 균질한 유 리상의 스펙트럼보다 상대적으로 농도가 상승한 것을 확 인할 수 있다.

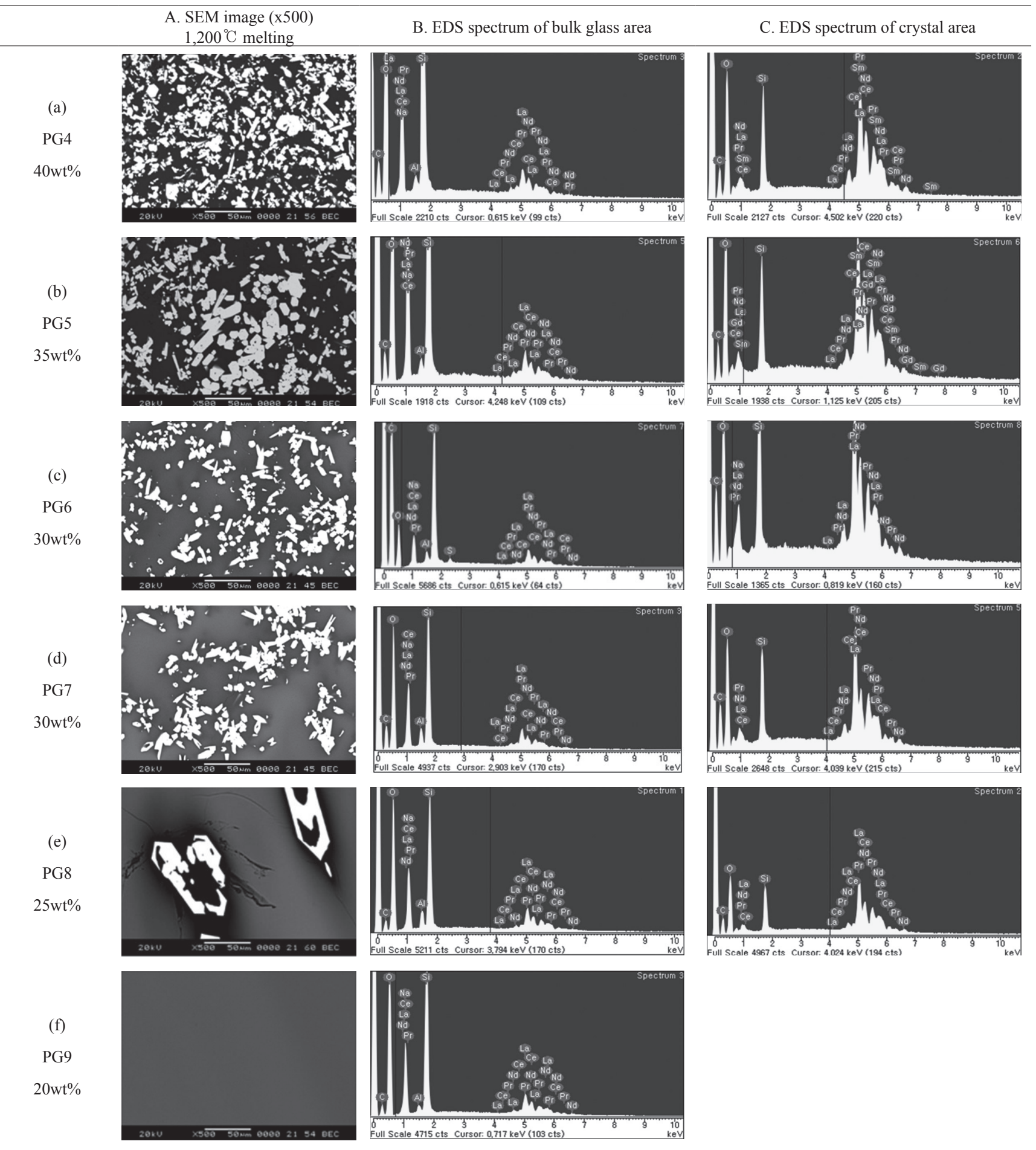

Fig. 4. SEM/EDS analysis for glass matrix and crystal of PG4 PG9. 


\section{3 상전이 현상 및 액상온도 분석}

상전이 현상 분석을 위해 열처리 후 시료 모습과 SEM/EDS 분석결과를 Fig. 5와 Fig. 6에 나타내었다. 열처리 후 PG8 은 meniscus와 백금도가니 경계면에서 모두 결정이 생성되 었지만 PG9는 결정이 생성되지 않았다. 결과적으로 PG9 의 액상온도(liquidus temperature)는 $950^{\circ} \mathrm{C}$ 이하인 것으 로 평가되었다.

\section{4 용해도 평가}

$1,300^{\circ} \mathrm{C}$ 로 용융 제조된 유리고화체 시료의 SEM 분석결과 를 Fig. 7 에 나타내었다. $1,200^{\circ} \mathrm{C}$ 로 용융 제조된 유리고화 체 시료의 SEM 분석결과는 Fig. $4 \mathrm{~A}$ 에서 볼 수 있다. 현재 까지의 실험결과를 바탕으로 볼 때 붕규산 유리계 내 희토 류 8종 혼합에 대한 solubility는 온도 상승에 따라 증가하 였는데 $1,200^{\circ} \mathrm{C}$ 에서 $25 \mathrm{wt} \%$ 미만, $1,300^{\circ} \mathrm{C}$ 에서 $30 \mathrm{wt} \%$ 미만 waste loading인 것으로 분석되었다.

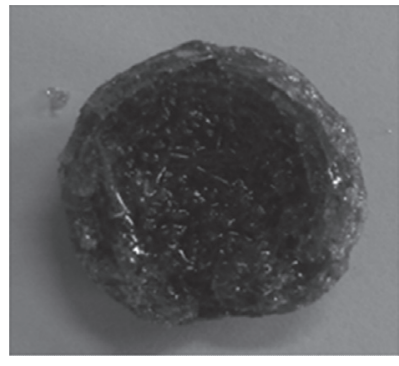

(a) HT-PG8

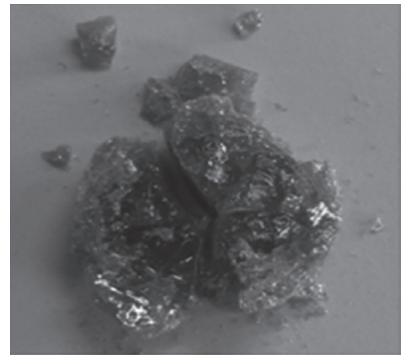

(b) HT-PG9
Fig. 5. Status of PG8 \& PG9 after heat treatment at $950^{\circ} \mathrm{C}$ for phase transition phenomena analysis.

\section{5 이차상 분석}

희토류 산화물을 $35 \mathrm{wt} \%$ 와 $30 \mathrm{wt} \%$ 투입하여 $1,200{ }^{\circ} \mathrm{C}$ 에 서 제조한 PG5와 PG7의 유리 내 이차상을 XRD로 분석 한 결과, Fig. 8에서 보는바와 같이 neodymium oxide silicate $\left[\mathrm{Nd}_{9} \cdot 33\left(\mathrm{SiO}_{4}\right) \cdot 6 \mathrm{O}_{2}\right]$ 와 유사한 결정으로 분석되 었다. $\mathrm{EDS}$ 결과와 교차 평가한 결과 $\mathrm{Nd}$ 자리는 다른 희 토류 원소들이 일정한 분율로 공유하고 있을 것으로 판 단된다.

\section{6 운전 용이성 평가}

유리제조의 운전용이성 평가에 필요한 점도와 전기전 도도를 측정한 결과를 Fig. 9과 Fig. 10에 나타내었다. 일 반적으로 운전이 용이한 점도는 100 poise 이하이고 전 기전도도는 $1 \mathrm{~S} / \mathrm{cm}$ 이상인데, PG8-1, PG9-1 모두 용융 온도 $1,200 \sim 1,300^{\circ} \mathrm{C}$ 범위에서 점도 100 poise 이하, 전 기전도도 $1 \mathrm{~S} / \mathrm{cm}$ 이상을 나타내고 있어 유도가열식 저온 용융설비에서의 운전 용이성이 매우 양호한 것으로 평가 되었다.

\section{7 유리의 화학적 내구성 계산결과}

Table 3에서 보는바와 같이 6종 유리의 화학적 내구성 은 매우 양호한 것으로 평가되었다. 참고로 7일 PCT의 기 준치는 $2 \mathrm{~g} / \mathrm{m}^{3}$ 이하를 적용했다. 단, 이 결과는 컴퓨터 프 로그램을 이용한 결과이므로 향후 실험적 분석을 수행할 계획이다.

(a) HT-PG8

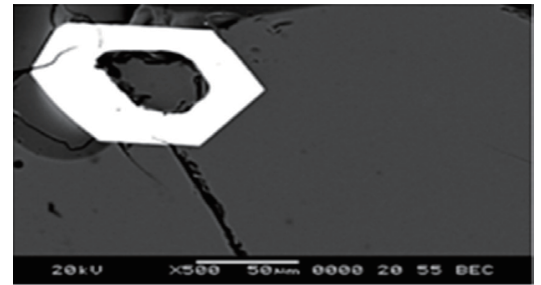

SEM image(x500)

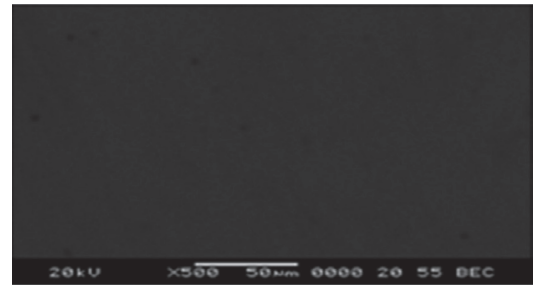

SEM image(x500)

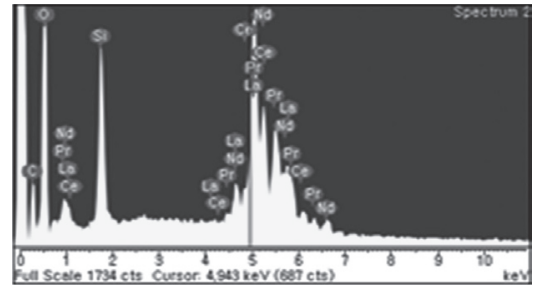

EDS spectrum of crystal area

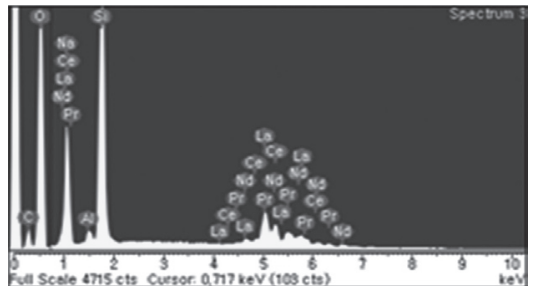

EDS spectrum of bulk glass area

Fig. 6. Phase transition phenomena analysis(SEM/EDS micrographs). 


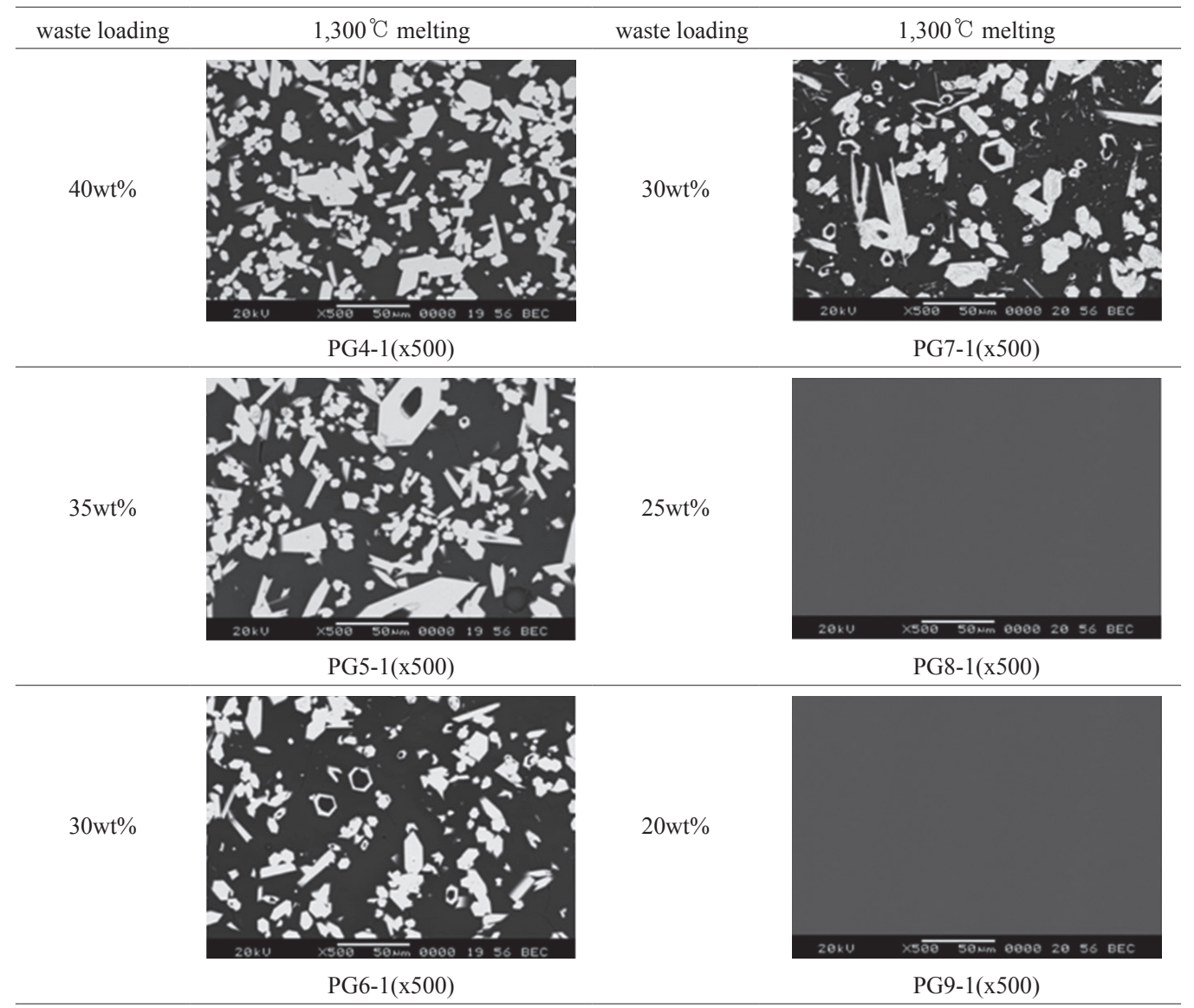

Fig. 7. Solubility evaluation(SEM micrographs).

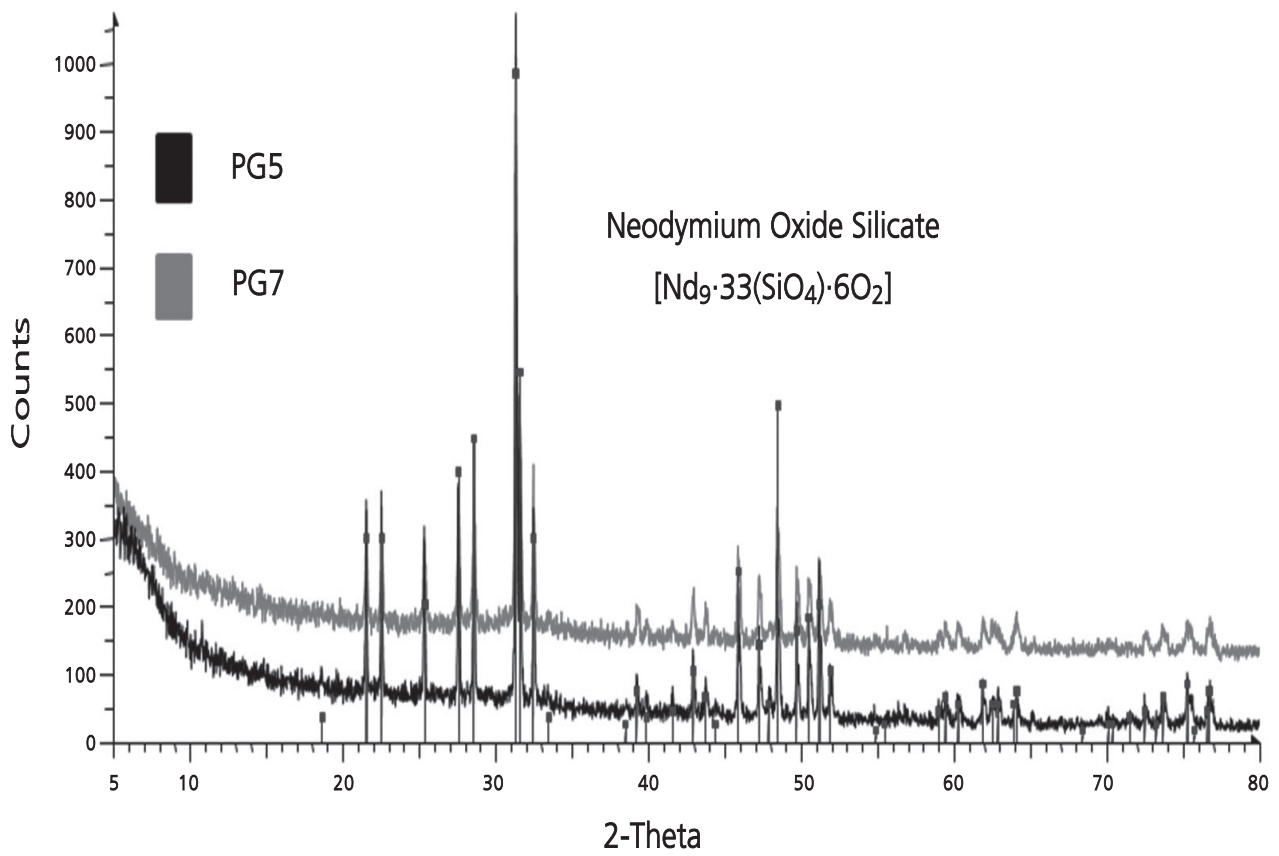

Fig. 8. XRD analysis for secondary phase of PG5 \& PG7. 
Table 3. 7-day PCT leach rates of major elements in glass $\left(\mathrm{g} / \mathrm{m}^{2}\right)$

\begin{tabular}{ccccccc}
\hline element & PG4 & PG5 & PG6 & PG7 & PG8 & PG9 \\
\hline $\mathrm{Si}$ & 0.03 & 0.04 & 0.06 & 0.06 & 0.08 & 0.12 \\
\hline $\mathrm{B}$ & 0.01 & 0.03 & 0.04 & 0.04 & 0.08 & 0.13 \\
\hline $\mathrm{Li}$ & 0.04 & 0.06 & 0.10 & 0.10 & 0.16 & 0.26 \\
\hline $\mathrm{Na}$ & 0.01 & 0.01 & 0.02 & 0.02 & 0.04 & 0.06 \\
\hline
\end{tabular}

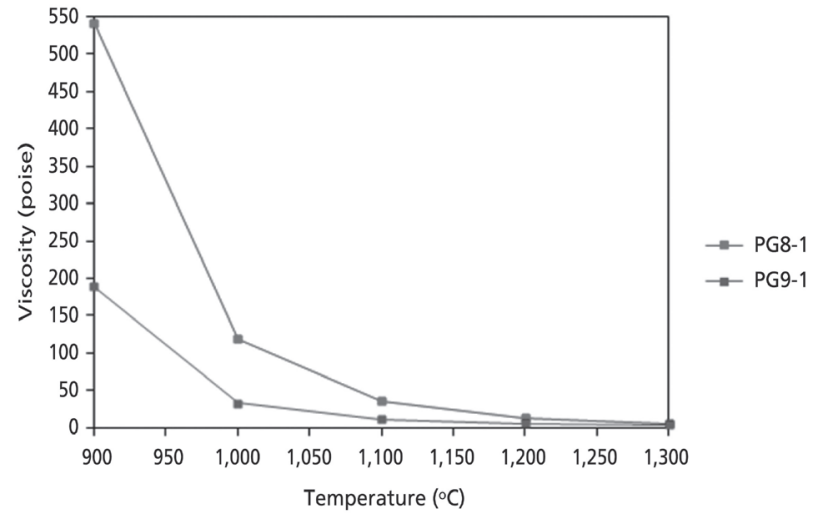

Fig. 9. Viscosity(PG8-1, PG9-1).

\section{4. 결 론}

파이로그린공정의 염폐기물처리과정 공융염에서 분리 되는 산화물 형태의 주요 희토류폐기물은 $\mathrm{Y}, \mathrm{La}, \mathrm{Ce}, \mathrm{Pr}$, $\mathrm{Nd}, \mathrm{Sm}, \mathrm{Eu}, \mathrm{Gd}$ 등 8핵종인데 이들의 물리적 특성은 cubic 및 tetragonal의 안정적 구조로 용융점 $\left(>2,200^{\circ} \mathrm{C}\right)$ 및 휘발 점 $\left(>3,500^{\circ} \mathrm{C}\right)$ 이 높다. 붕규산 유리계 내에서 PWR 사용후 핵연료 속에 포함된 희토류 비율로 구성된 희토류 8핵종 폐기물의 유리화 및 유리세라믹화 타당성 평가를 위하여 6 종의 유리조성을 개발하였다.

8 종의 희토류 산화물 혼합에 대한 solubility는 $1,200^{\circ} \mathrm{C}$ 에서 $25 \mathrm{wt} \%$ 미만, $1,300{ }^{\circ} \mathrm{C}$ 에서 $30 \mathrm{wt} \%$ 미만 waste loading으로 온도 상승에 따라 증가하는 것으로 나타났으며 액상온도(liquidus temperature)는 20wt\% waste loading의 균질한 유리에서 $950^{\circ} \mathrm{C}$ 이하로 평가되었다. 희 토류 산화물의 유리매질 내 solubility 이상에서는 희토 류-oxide-silicate 결정이 생성된 유리세라믹을 이차상으 로 형성하였으며 20 25wt\% waste loading의 표면균질 성이 양호한 시료는 용융온도 $1,200 ~ 1,300^{\circ} \mathrm{C}$ 범위에서 점도 100 poise 이하, 전기전도도 $1 \mathrm{~S} / \mathrm{cm}$ 이상으로 유도 가열식 저온용융로설비에서의 운전 용이성이 매우 양호 한 것으로 평가되었다.

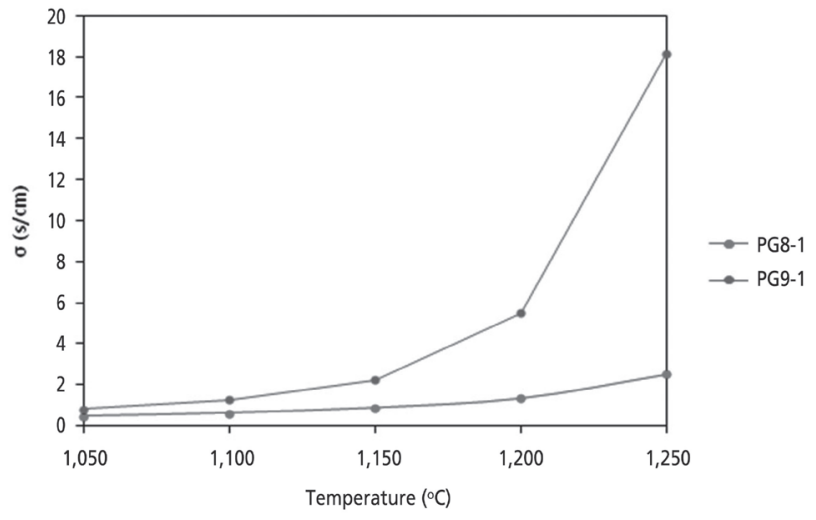

Fig. 10. Electrical conductivity(PG8-1, PG9-1).

향후 연구에서는 $1,400^{\circ} \mathrm{C}$ 유리용융에서의 추가적인 희토류 solubility 평가, base glass 성분변화를 통한 추 가 유리조성 개발, 유리의 주요 공정변수(점도, 전기전 도도 등) 측정, 유리의 화학적 내구성 평가를 위한 침출 시험(PCT) 수행, 유리세라믹 내 결정의 미세구조 분석 을 위한 XRD (X-ray Diffraction) 측정, 고온 환경에서 의 희토류 원소별 휘발특성에 관한 문헌조사 등을 계획 하고 있다.

\section{REFERENCES}

[1] Tae-Gyo Lee, Yong-Jun Jo, Hee-Cheol Yang, Han-Su Lee and In-Tae Kim, "Recycling technology of eutectic salt waste generated in oxide spent fuel pyroprocessing", Proceedings of the Korean Radioactive Waste Society Conference, 7(2), pp. 169-170 (2009).

[2] In-Tae Kim, Yong-Jun Jo, Hee-Cheol Yang, ByeongGil An, Hwan-Seo Park, Hee-Cheol Eun and Han-Su Lee, "Removal and immobilization of rare earth nuclides from eutectic salt waste generated in PWR fuel pyroprocessing", Proceedings of the Korean Radioactive Waste Society Conference, 6(2), pp. 122-123 
(2008).

[3] Tae-Kyo Lee, Yong-Jun Jo, In-Tae Kim and Han-Su Lee, "Salts recovery process and rare earth chlorides separation from eutectic salt waste generated in spent fuel pyroprocessing" Proceedings of the Korean Radioactive Waste Society Conference, 8(1), pp. 113114 (2010).

[4] Yong-Jun Jo, Gil-Ho Park, Han-Su Lee and In-Tae Kim, "Oxidation/precipitation characteristics of rare earth nuclides within eutectic salt waste by using Labscale devices" Proceedings of the Korean Radioactive Waste Society Conference, 7(1), pp. 292-293 (2009).

[5] C.Lopez, X.Deschanels, J.M.Bart, J.M.Boubals, "Solubility of Actinide Surrogates in Nuclear Glasses", J. of Nuclear Materials, 312, pp. 76-80 (2003)

[6] J. Campbell, C. L. Hoenig, F. Ryerson, M. Guiman, R. V. Konynenburg and R. Rozsa, "Properties of SYNROC-D nuclear wasteform: A-State-the-Art Review", UVRL-53240 (1982).

[7] F. Poitrasson, E. Olekers, J. Schott, and J. M. Montel, "Experimental determination of synthetic $\mathrm{NdPO}_{4}$ monazite end-member solubility in water from $21^{\circ} \mathrm{C}$ to $300^{\circ} \mathrm{C}$ : Imbrications of rare earth element mobility in crustal fluids", Geochemica et Cosmochimica Acta, 40(10), pp. 2207-2221 (2004).

[8] Byung-Gil Ahn, Hwan-Seo Park, Hwan-Young Kim, Han-Soo Lee and In-Tae Kim, "Immobilization of Radioactive Rare Earth oxide Waste by Solid Phase Sintering", J. of the Korean Radioactive Waste Society, 8(1), pp.49-56 (2010).

[9] K. Vinjamuri, S. T. Wood, L. O. Nelson, GLASSFORMVersion 1.1: An Algorithm for Generating Preliminary Glass Formulations for Waste Streams, INEEL/EXT98-00269 (2000). 